\title{
UJI PUPUK PETROGANIK DAN GRAND K TERHADAP PERTUMBUHAN SERTA PRODUKSI TANAMAN KACANG TANAH (Arachis hypogaea L.)
}

\author{
Petroganic and Grand K Fertilizer Test on Growth and Production \\ of Peanut (Arachis hypogaea L.)
}

\author{
Jack Swanri Pakpahan, Siti Zahrah, Sulhaswardi \\ Program Studi Agroteknologi, Fakultas Pertanian Universitas Islam Riau \\ Jl. Khaharuddin Nasution No.113 Pekanbaru. 28284 \\ Telp: 0761-674681; Fax: 0761-674681 \\ Email: jackswanripakpahan@ student.uir.ac.id
}

\begin{abstract}
This research was carried out at the Experimental Garden of the Faculty of Agriculture, Riau Islamic University, Pekanbaru, from April to July 2019. The purpose of this study was to determine the effect of the interaction and main fertilizer of Petroganik and Grand $\mathrm{K}$ on the growth and production of peanut plants. The method used was a Completely Randomized Design which consisted of two factors. The first factor was P (Petroganik) and the second factor was K (Grand-K), each of which consisted of 4 levels of treatment, so that there were 16 treatment combinations. Each treatment consisted of 3 replications, so there were 48 experimental plots, consisting of 12 plants and 3 plants as observational samples with the total number was 576 plants. Data from the latest observations were analyzed by variance (ANOVA) and further tested with the significant difference in honesty (BNJ) at the 5\% significant level. The results showed the interaction of Petroganik and Grand-K fertilizers significantly affected plant height, relative growth rate and weight of 100 seeds. The best combination of treatment in the application of Petroganic fertilizer was $81 \mathrm{~g} / \mathrm{plot}$ and Grand $\mathrm{K}$ fertilizer was $14 \mathrm{~g} /$ plot (P3K2). The main effect of real Petroganik fertilizer on all parameters of observation with the best treatment was the application of Petroganic fertilizer as much as $81 \mathrm{~g} / \mathrm{plot}$ (P3). The main effect of Grand $\mathrm{K}$ fertilizer was significant on all parameters observed with the best treatment was the aplication of Grand $\mathrm{K}$ fertilizer of $14 \mathrm{~g} / \mathrm{plot}(\mathrm{K} 2)$.
\end{abstract}

Keywords: Petroganik Fertilizer, Grand K, Peanuts

\begin{abstract}
ABSTRAK
Penelitian ini telah dilaksanakan di Kebun Percobaan Fakultas Pertanian Universitas Islam Riau, Pekanbaru yang dilaksanakan pada bulan April sampai Juli 2019. Tujuan penelitian ini untuk mengetahui pengaruh interaksi dan utama pupuk Petroganik dan Grand K terhadap pertumbuhan serta produksi tanaman kacang tanah. Rancangan yang digunakan adalah Rancangan Acak Lengkap Faktorial yang terdiri dari dua faktor. Faktor pertama adalah P (Petroganik) dan faktor kedua adalah $\mathrm{K}$ (Grand-K) yang masing-masing terdiri dari 4 taraf perlakuan sehingga terdapat 16 kombinasi perlakuan. Masing-masing perlakuan terdiri dari 3 ulangan, sehingga terdapat 48 plot percobaan yang setiap plotnya terdiri dari 12 tanaman dan 3 tanaman sebagai sampel pengamatan maka jumlah keseluruhan yaitu 576 tanaman. Data hasil pengamatan terakhir dianalisis ragam (Anova) dan di uji lanjut beda nyata jujur (BNJ) pada taraf 5\%. Hasil penelitian menunjukkan interaksi pupuk Petroganik dan Grand-K berpengaruh nyata terhadap tinggi tanaman, laju pertumbuhan relatif dan berat 100 biji. Kombinasi perlakuan terbaik pada pemberian pupuk Petroganik sebanyak $81 \mathrm{~g} / \mathrm{plot}$ dan pupuk Grand K sebanyak 14 g/plot (P3K2). Pengaruh utama pupuk Petroganik nyata terhadap semua parameter pengamatan dengan perlakuan terbaik adalah pemberian pupuk Petroganik sebanyak $81 \mathrm{~g} /$ plot (P3). Pengaruh utama pupuk Grand K nyata terhadap semua parameter pengamatan dengan perlakuan terbaik adalah pemberian pupuk Grand K sebanyak 14 g/plot (K2).
\end{abstract}




\section{PENDAHULUAN}

Kacang tanah (Arachis hypogaea L.) adalah komoditas tanaman pangan yang bernilai ekonomi cukup tinggi dan merupakan salah satu sumber protein dalam pola pangan penduduk Indonesia. Kandungan gizi yang terdapat pada kacang tanah terdiri dari minyak $40-48 \%$, protein yang tinggi 26-28\%, karbohidrat $18 \%$, zat besi $13 \%$, vitamin E $23 \%$, vitamin $\mathrm{B}$ kompleks, fosfor, vitamin $\mathrm{A}$, vitamin $\mathrm{K}$ dan kalsium (Badan Litbang Pertanian, 2012).

Produksi kacang tanah di Riau selalu mengalami penurunan, yaitu tahun 2015 luas panen 1.081 ha produksi mencapai 1.036 ton, mengalami penurunan tahun 2016 dengan luas panen 959,5 ha produksi 913 ton, dan pada tahun 2017 dengan luas panen 802,2 ha produksi yaitu 798 ton dengan produktivitas 9,95 kw/ha (Dinas Tanaman Pangan, Hortikultura dan Perkebunan Provinsi Riau, 2017).

Rendahnya produksi kacang tanah di Riau disebabkan kesuburan tanah yang dipengaruhi oleh rendahnya kadar C-organik yang terdapat didalam tanah, produktivitas tanah yang mengalami penurunan, penggunaan pupuk organik yang masih rendah dan masih rendahnya pengetahuan petani mengenai teknik budidaya. Salah satu cara yang dapat dilakukan untuk meningkatkan produksi kacang tanah adalah dengan teknik budidaya yaitu melalui pemupukan yang berimbang. Pupuk yang digunakan dapat berupa pupuk organik maupun pupuk anorganik.

Petroganik merupakan salah satu pupuk organik yang sudah diolah serta efektif dan efisien untuk diaplikasikan. Bahan baku pertoganik terdiri dari kotoran sapi, kotoran ayam, kotoran kambing, limbah pabrik gula (blo-thong), limbah pabrik sawit (tandan kosong), mixtro, suplemen, dan filler (kapur/tanah liat). Pupuk petroganik selain mengandung $\mathrm{C}$-organik yang tinggi yakni $\geq 15 \%$, juga mengandung unsur hara lain seperti: $\mathrm{N}, \mathrm{P}_{2} \mathrm{O}_{5}$ dan $\mathrm{K}_{2} \mathrm{O}$ sebesar $4 \%$, pupuk petroganik juga mengandung unsur hara mikro yakni $\mathrm{Fe}$, Mn dan $\mathrm{Zn}$ (Petrokimia Gresik, 2012).

Kalium merupakan hara yang banyak diserap oleh tanaman kacang tanah setelah unsur hara $\mathrm{N}$ dan $\mathrm{P}$. Peranan kalium bagi kacang-kacangan terutama untuk proses pembentukan biji. Pupuk Grand-K adalah pupuk majemuk dengan kandungan nitrogen dan kalium yang mudah dan cepat diserap tanaman, berguna untuk merangsang pembungaan, pembuahan tanaman, meningkatkan kualitas hasil panen serta memperkuat tumbuh tanaman agar daun, bunga, dan buah tidak mudah gugur. Pupuk Grand-K mengandung unsur hara makro seperti $\mathrm{N}(13 \%)$, $\mathrm{P}_{2} \mathrm{O}_{5}(0,03 \%), \mathrm{K}_{2} \mathrm{O}(46 \%)$. Selain itu, pupuk ini juga mengandung unsur lain seperti $\mathrm{Na}, \mathrm{Ca}, \mathrm{Zn}$, $\mathrm{Fe}, \mathrm{Mn}, \mathrm{Mg}$, dan $\mathrm{Cu}$ dalam jumlah yang sedikit (Tanindo Subur Prima dalam Syahfitri dkk, 2019)

Penggunaan pupuk Petroganik diharapkan mampu memperbaiki sifat fisika, kimia, biologi serta dapat mengoptimalkan penyerapan unsur hara yang terkandung pada pupuk Grand-K. Sementara itu penggunaan pupuk Grand $\mathrm{K}$ diharapkan mampu menyediakan unsur hara yang dibutuhkan tanaman, sehingga kombinasi kedua pupuk tersebut diharapkan dapat meningkatkan pertumbuhan serta produksi yang dihasilkan oleh tanaman kacang tanah.

\section{BAHAN DAN METODE}

Penelitian ini telah dilaksanakan di Kebun Percobaan Fakultas Pertanian Universitas Islam Riau, Pekanbaru yang dilaksanakan pada bulan April sampai Juli 2019. Penelitian ini menggunakan Rancangan Acak Lengkap (RAL) Faktorial dengan 3 ulangan. faktor pertama terdiri dari 4 taraf perlakuan yaitu tanpa pupuk Petroganik, pupuk Petroganik (27 g/plot), pupuk Petroganik (54 $\mathrm{g} / \mathrm{plot})$, dan pupuk Petroganik (81 g/plot). Faktor kedua terdiri dari 4 taraf perlakuan yaitu tanpa pupuk Grand-K, pupuk Grand K (7 g/plot), pupuk Grand K (14 g/plot), pupuk Grand K (21 g/plot). Data hasil pengamatan dari masing-masing perlakuan dianalisis secara statistik. Apabila F hitung lebih besar dari F tabel maka akan dilanjutkan dengan uji lanjut beda nyata jujur (BNJ) pada taraf $5 \%$.

\section{HASIL DAN PEMBAHASAN}

\section{Tinggi Tanaman (cm)}

Hasil pengamatan tinggi tanaman kacang tanah setelah dianalisis ragam menunjukkan 
pengaruh interaksi dan utama pupuk Petroganik dan Grand $\mathrm{K}$ berpengaruh nyata terhadap tinggi tanaman kacang tanah. Hasil uji beda nyata jujur $(\mathrm{BNJ})$ pada taraf $5 \%$ dapat dilihat pada Tabel 1.

Tabel 1. Rata-rata tinggi tanaman kacang tanah pada umur 28 hst dengan pemberian pupuk petroganik dan pupuk grand $\mathrm{k}(\mathrm{cm})$

\begin{tabular}{|c|c|c|c|c|c|}
\hline \multirow{2}{*}{$\begin{array}{c}\text { Petroganik } \\
\text { (g/plot) }\end{array}$} & \multicolumn{4}{|c|}{ Grand K (g/plot) } & \multirow{2}{*}{ Rerata } \\
\hline & K0 (0) & K1 (7) & K2 (14) & K3 (21) & \\
\hline P0 (0) & $22,33 \mathrm{~h}$ & $24,70 \mathrm{~g}$ & $28,05 \mathrm{~b}-\mathrm{e}$ & $26,90 \mathrm{c}-\mathrm{g}$ & $25,50 \mathrm{~d}$ \\
\hline P1 (27) & $25,10 \mathrm{f}-\mathrm{g}$ & $26,37 \mathrm{~d}-\mathrm{g}$ & $28,73 \mathrm{bc}$ & $27,17 \mathrm{c}-\mathrm{f}$ & $26,84 \mathrm{c}$ \\
\hline P2 (54) & $26,22 \mathrm{e}-\mathrm{g}$ & $27,38 \mathrm{c}-\mathrm{e}$ & 29,17 a-c & $28,30 \mathrm{~b}-\mathrm{e}$ & $27,77 \mathrm{~b}$ \\
\hline P3 (81) & $28,57 \mathrm{~b}-\mathrm{d}$ & $30,07 \mathrm{ab}$ & $31,10 \mathrm{a}$ & $30,27 \mathrm{ab}$ & $30,00 \mathrm{a}$ \\
\hline Rerata & $25,55 \mathrm{~d}$ & $27,13 \mathrm{c}$ & $29,26 \mathrm{a}$ & $28,16 \mathrm{~b}$ & \\
\hline
\end{tabular}

Angka-angka pada baris dan kolom yang diikuti huruf kecil yang sama menunjukkan tidak berbeda nyata menurut uji lanjut BNJ pada taraf $5 \%$.

Pada Tabel 1 terlihat dosis pupuk Petroganik 81 g/plot dan Grand K 14 g/plot (P3K2) menghasilkan tinggi tanaman tertinggi yaitu $31,10 \mathrm{~cm}$. Hal ini dikarenakan masingmasing pupuk memberikan pengaruh terhadap pertumbuhan tinggi tanaman, seperti pupuk petroganik yang mengandung C-organik $15 \%$ mam pu meningkatkan kesuburan di dalam tanah sehingga tanaman dapat menyerap unsur hara nitrogen yang terdapat pada pupuk Grand $\mathrm{K}$ dengan optimal.

Untuk melihat grafik pertumbuhan tinggi tanaman kacang tanah pada masing-masing perlakuan dengan pemberiaan pupuk Petroganik dan Grand K dapat dilihat pada Gambar 1.

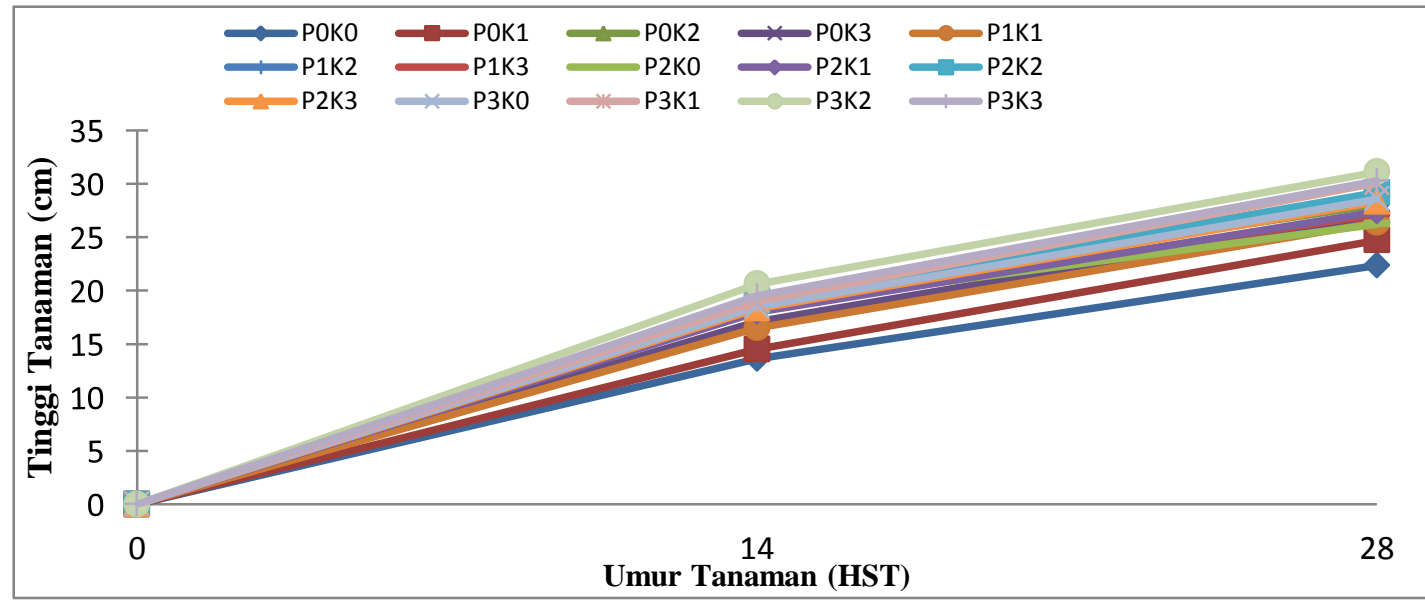

Gambar 1. Grafik Pertumbuhan Tinggi Tanaman Kacang Tanah dengan Pemberian Pupuk Petroganik dan Pupuk Grand K (cm)

Pada Gambar 1 diatas, memperlihatkan perlakuan P3K2 mengalami peningkatan tinggi tanaman yang cukup cepat dibandingkan perlakuan P0K0. Pada saat tanam sampai 14 hst terlihat grafik pertumbuhan tanaman yang sangat cepat dikarenakan unsur hara yang tersedia dimanfaatkan untuk pertumbuhan vegetatif. Sementara itu umur 14-28 hst pada grafik menunjukkan pertumbuhan yang cukup lambat, hal ini dikarenakan tanaman telah memasuki fase pertumbuhan generatif sehingga nutrisi yang diserap oleh tanaman dialokasikan untuk membentuk bagian generatif tanaman.

Raharjo dalam Marpaung (2018), menyatakan terjadinya penambahan tinggi batang disebabkan peristiwa pembelahan dan pemanjangan sel yang didominasi bagian ujung pucuk. Unsur hara bagi tanaman dapat mengaktifkan aktifitas sel-sel meristimatik pada ujung batang tanaman, serta mendorong dan 
mempelancar proses fotosintesis pada daun dan dapat meningkatkan penumpukan bahan organik dan selanjutnya akan menigkatkan pertumbuhan tinggi tanaman.

Kalium sangat dibutuhkan tanaman untuk pertumbuhan dan pembentukan bagian vegetatif tanaman. Bel dalam Safuan dan Bahrun (2012), menyatakan bahwa pertumbuhan tanaman berkorelasi dengan penambahan konsentrasi kalium pada daerah pembesaran. Bila tanaman kekurangan kalium maka pembesaran dan perpanjangan sel terhambat.

\section{Laju Pertumbuhan Relatif (g/hari)}

Hasil pengamatan laju pertumbuhan relatif tanaman kacang tanah pada umur 7-14, 14-21 dan 21-28 hst setelah dianalisis ragam menunjukkan secara interaksi maupun pengaruh utama pemberian pupuk Petroganik dan Grand $\mathrm{K}$ berpengaruh nyata terhadap laju pertumbuhan relatif tanaman kacang tanah. Hasil uji beda nyata jujur (BNJ) peda taraf 5\% dapat dilihat pada Tabel 2.

Tabel 2 menunjukkan perlakuan P3K2 menghasilkan laju pertumbuhan relatif tertinggi pada umur 7-28 hst. Hal ini menunjukkan seiring bertambahnya umur tanaman, maka semakin bertambah pula berat biomassa tanaman yang dapat dijadikan modal dalam membentuk bahan baru tanaman. Melalui fotosintesis maka tanaman akan lebih banyak menghasilkan asimilat yang sebagian tersimpan di dalam jaringan tanaman sehingga menghasilkan berat kering yang lebih tinggi.

Tanaman sangat membutuhkan unsur hara yang cukup untuk pertumbuahan vegetatif sehingga tersedianya unsur hara di dalam tanah sangat mempengaruhi pertumbuhan tanaman. Pupuk Petroganik dapat mempercepat pertumbuhan vegetatif tanaman melalui kandungan unsur nitrogen $(\mathrm{N})$ yang ada pada pupuk (Petrokimia Gersik, 2012). Menurut Hardjowigeno dalam Murdhiani (2016), fungsi kalium adalah untuk mengaktifkan kerja beberapa enzim (seperti enzim asetik thiokinase, aldolase, piruvat kinase, sintesa tepung, glutamil sintetase, suksinil Co-A dan ATP-ase), sehingga memacu translokasi karbohidrat dari akar tanaman ke organ tanaman yang lain, serta mempengaruhi pertumbuhan tanaman dan juga menambah jumlah daun dan luas daun pada tanaman.

Tabel 2. Rata-rata Laju Pertumbuhan Relatif Tanaman Kacang Tanah dengan Pemberian Pupuk Petroganik dan Pupuk Grand K (g/hari)

\begin{tabular}{|c|c|c|c|c|c|c|}
\hline \multirow{2}{*}{ HST } & \multirow{2}{*}{ Petroganik (g/plot) } & \multicolumn{4}{|c|}{ Grand K (g/plot) } & \multirow{2}{*}{ Rerata } \\
\hline & & K0 (0) & K1 (7) & K2 (14) & K3 (21) & \\
\hline \multirow{6}{*}{$7-14$} & P0 (0) & $0,019 \mathrm{~g}$ & $0,026 \mathrm{e}-\mathrm{g}$ & 0,036 a-d & $0,033 \mathrm{~b}-\mathrm{f}$ & $0,029 \mathrm{~b}$ \\
\hline & P1 (27) & $0,025 \mathrm{fg}$ & $0,027 \mathrm{~d}-\mathrm{g}$ & $0,038 \mathrm{abc}$ & $0,032 b-f$ & $0,031 \mathrm{~b}$ \\
\hline & P2 (54) & $0,026 \mathrm{fg}$ & $0,035 \mathrm{a}-\mathrm{e}$ & $0,040 \mathrm{ab}$ & $0,038 \mathrm{abc}$ & $0,034 \mathrm{a}$ \\
\hline & P3 (81) & $0,033 \mathrm{~b}-\mathrm{f}$ & $0,030 \mathrm{c}-\mathrm{f}$ & $0,043 \mathrm{a}$ & $0,039 \mathrm{abc}$ & $0,036 \mathrm{a}$ \\
\hline & Rerata & $0,026 \mathrm{~d}$ & $0,030 \mathrm{c}$ & $0,039 \mathrm{a}$ & $0,035 \mathrm{~b}$ & \\
\hline & $\mathrm{KK}=8,52 \%$ & & \multicolumn{2}{|c|}{ BNJ PK=0,0084 } & \multicolumn{2}{|c|}{ BNJ P\&K=0,0031 } \\
\hline \multirow{6}{*}{$14-21$} & P0 (0) & $0,044 \mathrm{~g}$ & 0,059 efg & $0,067 \mathrm{de}$ & 0,063 def & $0,058 \mathrm{c}$ \\
\hline & P1 (27) & $0,050 \mathrm{fg}$ & $0,053 \mathrm{efg}$ & $0,079 \mathrm{bcd}$ & $0,068 \mathrm{de}$ & $0,063 \mathrm{c}$ \\
\hline & P2 (54) & $0,056 \mathrm{efg}$ & 0,069 cde & $0,095 \mathrm{ab}$ & $0,089 \mathrm{ab}$ & $0,077 \mathrm{~b}$ \\
\hline & P3 (81) & 0,061 ef & $0,086 \mathrm{abc}$ & $0,102 \mathrm{a}$ & $0,092 \mathrm{ab}$ & $0,085 \mathrm{a}$ \\
\hline & Rerata & $0,053 \mathrm{~d}$ & $0,067 \mathrm{c}$ & $0,086 \mathrm{a}$ & $0,078 \mathrm{~b}$ & \\
\hline & $\mathrm{KK}=7,82 \%$ & & \multicolumn{2}{|c|}{ BNJ PK=0,0168 } & \multicolumn{2}{|c|}{ BNJ P\&K=0,0061 } \\
\hline \multirow{6}{*}{$21-28$} & P0 (0) & $0,063 \mathrm{f}$ & $0,071 \mathrm{def}$ & 0,085 cde & $0,079 \mathrm{c}-\mathrm{f}$ & $0,075 \mathrm{c}$ \\
\hline & P1 (27) & 0,068 ef & $0,073 \mathrm{c}-\mathrm{f}$ & $0,090 \mathrm{bcd}$ & 0,086 cde & $0,079 \mathrm{c}$ \\
\hline & P2 (54) & $0,076 \mathrm{c}-\mathrm{f}$ & $0,082 \mathrm{c}-\mathrm{f}$ & $0,115 \mathrm{a}$ & $0,092 \mathrm{bc}$ & $0,091 \mathrm{~b}$ \\
\hline & P3 (81) & $0,080 \mathrm{c}-\mathrm{f}$ & $0,089 \mathrm{bcd}$ & $0,124 \mathrm{a}$ & $0,107 \mathrm{ab}$ & $0,100 \mathrm{a}$ \\
\hline & Rerata & $0,072 \mathrm{~d}$ & $0,079 \mathrm{c}$ & $0,103 \mathrm{a}$ & $0,091 \mathrm{~b}$ & \\
\hline & $\mathrm{KK}=7,26 \%$ & & \multicolumn{2}{|c|}{ BNJ PK $=0,0190$} & \multicolumn{2}{|c|}{$\mathrm{BNJ} P \& K=0,0069$} \\
\hline
\end{tabular}

Angka-angka pada baris dan kolom yang diikuti huruf kecil yang sama menunjukkan tidak berbeda nyata menurut uji lanjut BNJ pada taraf $5 \%$ 


\section{Umur Berbunga (hst)}

Hasil pengamatan umur berbunga tanaman kacang tanah setelah dianalisis ragam, menunjukkan pengaruh interaksi pemberian pupuk Petroganik dan Grand K tidak berpengaruh nyata terhadap umur berbunga tanaman kacang tanah, tetapi pengaruh utama nyata terhadap umur berbunga tanaman kacang tanah. Hasil uji beda nyata jujur (BNJ) peda taraf 5\% dapat dilihat pada Tabel 3.

Data pada Tabel 3 menunjukkan pengaruh utama pupuk Petroganik terhadap umur berbunga yang tercapat dosis $81 \mathrm{~g} / \mathrm{plot}$ (P3) yaitu 24,83 hst. Hal ini diduga unsur fosfor (P) yang terkandung di dalam pupuk petroganik berperan dalam pertumbuhan generatif sehingga mempercepat umur berbungadan panen tanaman. Pernyataan ini sesuai dengan pendapat Sutedjo dalam Sarianti dkk, (2016) menyatakan unsur hara yang dibutuhkan tanaman pada fase generatif ialah unsur $\mathrm{P}$ yang berperan dalam pembentukan bunga dan buah. Jika kebutuhan unsur $\mathrm{P}$ terpenuhi secara maksimal, maka proses pembungaan akan semakin cepat.

Pada Tabel 3 juga menunjukkan umur berbunga tercepat pada pengaruh utama pupuk Grand $\mathrm{K}$ dosis 14 g/plot (K2) yaitu 24,75 hst. Hal ini dikarenakan pupuk Grand $\mathrm{K}$ memiliki kandungan unsur hara makro yang dibutuhkan oleh tanaman seperti halnya unsur hara kalium yang diserap dengan baik oleh tanaman kacang tanah sehingga dapat mempercepat munculnya bunga.

Tabel 3. Rata-rata Umur Berbunga Tanaman Kacang Tanah dengan Perlakuan Pupuk Petroganik dan Pupuk Grand K (hst)

\begin{tabular}{lllllc}
\hline \multirow{2}{*}{ Petroganik (g/plot) } & \multicolumn{3}{c}{ Grand K (g/plot) } & \multirow{2}{*}{ Rerata } \\
\cline { 2 - 5 } & K0 (0) & K1 (7) & K2 (14) & K3 (21) & $26,00 \mathrm{~b}$ \\
P0 (0) & 28,00 & 26,00 & 24,67 & 25,33 & $25,33 \mathrm{ab}$ \\
P1 (27) & 25,67 & 25,00 & 25,33 & 25,33 & $25,17 \mathrm{ab}$ \\
P2 (54) & 25,67 & 25,33 & 25,00 & 24,67 & $24,83 \mathrm{a}$ \\
P3 (81) & 25,33 & 25,00 & 24,00 & 25,00 & \\
\hline Rerata & $26,17 \mathrm{~b}$ & $25,33 \mathrm{ab}$ & $24,75 \mathrm{a}$ & $25,08 \mathrm{a}$ \\
\hline KK=3,56\% & \multicolumn{5}{c}{ BNJ P\&K=1,00 } \\
\hline
\end{tabular}

Angka-angka pada baris dan kolom yang diikuti huruf kecil yang sama menunjukkan tidak berbeda nyata menurut uji lanjut BNJ pada taraf $5 \%$.

\section{Umur Panen (hst)}

Hasil pengamatan umur panen tanaman kacang tanah setelah dianalisis ragam menunjukkan pengaruh interaksi pemberian pupuk Petroganik dan pupuk Grand K tidak memberikan pengaruh nyata terhadap umur panen, tetapi pengaruh utama nyata terhadap umur panen kacang tanah. Hasil uji beda nyata jujur (BNJ) peda taraf $5 \%$ dapat dilihat pada Tabel 4.

Tabel 4. Rata-rata Umur Panen Tanaman Kacang Tanah dengan Perlakuan Pupuk Petroganik dan Pupuk Grand K (hst)

\begin{tabular}{llllll}
\hline \multirow{2}{*}{ Petroganik (g/plot) } & \multicolumn{5}{c}{ Grand K (g/plot) } \\
\cline { 2 - 5 } & K0 $(0)$ & K1 $(7)$ & K2 $(14)$ & K3 $(21)$ & Rerata \\
\hline P0 (0) & 95,00 & 94,33 & 92,00 & 93,33 & $93,67 \mathrm{c}$ \\
P1 (27) & 93,67 & 93,00 & 91,33 & 93,00 & $92,75 \mathrm{bc}$ \\
P2 (54) & 92,67 & 92,67 & 90,67 & 91,67 & $91,92 \mathrm{ab}$ \\
P3 (81) & 92,33 & 92,00 & 90,33 & 90,67 & $91,33 \mathrm{a}$ \\
\hline Rerata & $93,42 \mathrm{c}$ & $93,00 \mathrm{bc}$ & $91,08 \mathrm{a}$ & $92,17 \mathrm{ab}$ & \\
\hline KK= 1,14 \% & \multicolumn{5}{c}{ BNJ P\&K=1,16 } \\
\hline
\end{tabular}

Angka-angka pada baris dan kolom yang diikuti huruf kecil yang sama menunjukkan tidak berbeda nyata menurut uji lanjut BNJ pada taraf $5 \%$.

Data pada Tabel 4 menunjukkan pengaruh utama pemberian pupuk Petroganik terhadap umur panen yang tercepat dosis 81 g/plot (P3) yaitu 91,33 hst. Keuntungan dengan menggunakan pupuk organik adalah tanah menjadi gembur, sehingga pertumbuhan akar 
akan menjadi lebih baik dan memberikan dampak yang positif terhadap hasil tanaman (Sutanto dalam Marpaung, 2018).

Pada Tabel 4 juga menunjukkan pengaruh utama pupuk Grand K terhadap umur panan tercepat dosis $14 \mathrm{~g} / \mathrm{plot}(\mathrm{K} 2)$ yaitu 91,08 hst. Semakin cepat tanaman berbunga maka semakin cepat pula umur panen tanaman tersebut. Hal ini disebabkan karena pemasakan buah pada tanaman yang muncul bunga terlebih dahulu akan efektif dengan rentan waktu yang sama dalam pematangan buah. Menurut Wahyudi dalam Marbun (2019), kalium dapat meningkatkan pembentukan dan melancarkan distribusi asimilat sehingga sumber cadangan makanan meningkat dan mengacu pertumbuhan serta perkembangan buah lebih maksimal, dengan semakin meningkatnya asimilat yang tersimpan maka buah akan lebih cepat membesar dan memenuhi kriteria panen.

\section{Jumlah Polong Per Tanaman (Buah)}

Hasil pengamatan terhadap jumlah polong per tanaman kacang tanah setelah dianalisis ragam, menunjukkan bahwa pengaruh interaksi pemberian pupuk Petroganik dan pupuk Grand $\mathrm{K}$ tidak memberikan pengaruh nyata, tetapi pengaruh utama nyata terhadap jumlah polong per tanaman. Hasil uji beda nyata jujur (BNJ) peda taraf 5\% dapat dilihat pada Tabel 5.

Data pada Tabel 5 menunjukkan bahwa pengaruh utama pemberian pupuk Petroganik terhadap jumlah polong per tanaman yang tertinggi yaitu perlakuan P3 (81 g/plot) dengan jumlah polong sebanyak 42,58 buah dan berbeda nyata dengan perlakuan lainnya.

Tabel 5. Rata-rata Jumlah Polong Per Tanaman Kacang Tanah dengan Pemberiaan Pupuk Petroganik dan Pupuk Grand K (buah)

\begin{tabular}{|c|c|c|c|c|c|}
\hline \multirow{2}{*}{ Petroganik (g/plot) } & \multicolumn{4}{|c|}{ Grand K (g/plot) } & \multirow{2}{*}{ Rerata } \\
\hline & K0 (0) & K1 (7) & K2 (14) & K3 (21) & \\
\hline P0 (0) & 25,67 & 27,33 & 34,33 & 30,67 & $29,50 \mathrm{~d}$ \\
\hline P1 (27) & 29,33 & 32,33 & 39,33 & 35,67 & $34,16 \mathrm{c}$ \\
\hline P2 (54) & 36,33 & 37,33 & 43,00 & 39,67 & $39,08 \mathrm{~b}$ \\
\hline P3 (81) & 39,33 & 42,33 & 45,33 & 43,33 & $42,58 \mathrm{a}$ \\
\hline Rerata & $32,66 \mathrm{c}$ & $34,83 \mathrm{bc}$ & $40,50 \mathrm{a}$ & $37,33 \mathrm{~b}$ & \\
\hline $\mathrm{KK}=6.88 \%$ & & & BNJ P 8 & .77 & \\
\hline
\end{tabular}

Angka-angka pada baris dan kolom yang diikuti huruf kecil yang sama menunjukkan tidak berbeda nyata menurut uji lanjut BNJ pada taraf 5\%.

Sutikno dalam Huda (2018), menyatakan bahwa unsur hara yang tersedia dan diserap oleh tanaman dengan jumlah yang tepat dan seimbang mampu meningkatkan pembentukan buah akibatnya jumlah buah lebih banyak dan berpengaruh pada berat buah, yaitu berat buah menjadi lebih tinggi. Kondisi tanah yang baik mampu mendukang ketersediaan dan penyerapan unsur hara oleh tanaman kacang tanah lebih maksimal dari pada kondisi tanah yang kurang baik.

Pada Tabel 5 juga menunjukkan pengaruh utama pupuk Grand K dengan dosis $14 \mathrm{~g} / \mathrm{plot}$ (K2) memiliki jumlah polong terbanyak yaitu 40,50 buah. Rosmarkum dalam Yulhasmir (2009), menyatakan apabila tanaman kacang tanah kekurangan $\mathrm{K}$, maka banyak proses yang tidak berjalan dengan baik, misalnya terjadinya akumulasi karbohidrat, menurunnya kadar pati dan akumulasi senyawa nitrogen dalam tanaman, karena fungsi $\mathrm{K}$ adalah: membentuk dan mengangkut karbohidrat, sebagai katalisator dalam pembentuk protein, menaikkan pertumbuhan jaringan meristem, mengatur pergerakan stomata, mengaktifkan enzim, meningkatkan karbohidrat dan gula dalam buah dan biji tanaman menjadi lebih berisi serta padat.

\section{Berat Polong Kering Per Tanaman (g)}

Hasil pengamatan berat polong kering kacang tanah setelah dianalisis ragam (Lampiran 4f), menunjukkan pengaruh interaksi pemberian pupuk Petroganik dan Grand K tidak memberikan pengaruh nyata, tetapi pengaruh utama nyata terhadap berat polong kering kacang tanah. Hasil uji beda nyata jujur (BNJ) dapat dilihat pada Tabel 6. 
Tabel 6 Rata-rata Berat Polong Kering Kacang Tanah dengan Pemberian Pupuk Petroganik dan Pupuk Grand K (g)

\begin{tabular}{|c|c|c|c|c|c|}
\hline \multirow{2}{*}{ Petroganik (g/plot) } & \multicolumn{4}{|c|}{ Grand K (g/plot) } & \multirow{2}{*}{ Rerata } \\
\hline & K0 (0) & K1 (7) & K2 (14) & K3 (21) & \\
\hline P0 (0) & 26,24 & 28,43 & 38,96 & 34,57 & $32,04 \mathrm{c}$ \\
\hline P1 (27) & 31,87 & 36,29 & 41,03 & 38,17 & $36,84 \mathrm{c}$ \\
\hline P2 (54) & 38,60 & 39,10 & 43,07 & 41,24 & $40,50 \mathrm{~b}$ \\
\hline P3 (81) & 40,68 & 43,15 & 46,38 & 43,94 & $43,54 \mathrm{a}$ \\
\hline Rerata & $34,35 \mathrm{c}$ & $36,74 \mathrm{bc}$ & $42,36 \mathrm{a}$ & $39,48 \mathrm{~b}$ & \\
\hline $\mathrm{KK}=6,78 \%$ & \multicolumn{5}{|c|}{ BNJ $P \& K=2,87$} \\
\hline
\end{tabular}

Angka-angka pada baris dan kolom yang diikuti huruf kecil yang sama menunjukkan tidak berbeda nyata menurut uji lanjut BNJ pada taraf $5 \%$.

Data pada Tabel 6 menunjukkan bahwa pengaruh utama pemberian pupuk Petroganik terhadap berat polong kering per tanaman terberat dosis $81 \mathrm{~g} / \mathrm{plot}(\mathrm{P} 3)$ dengan berat 43,54 g. Pupuk Petroganik memberikan nutrisi tanaman melalui unsur hara makro yang terdapat pada pupuk yaitu $\mathrm{N}, \mathrm{P}$ dan $\mathrm{K}$. Petroganik juga mempengaruhi produktivitas tanah melalui kandungan $\mathrm{C}$-organik yang tinggi yaitu $>15 \%$. Kandungan C-organik erat hubungan dengan tingkat kesuburan tanah jika kandungan organik di dalam tanah tinggi maka kemampuan tanaman menyerap unsur hara meningkat.

Data pada Tabel 6 juga memperlihatkan pengaruh utama pupuk Grand $\mathrm{K}$ pada dosis 14/plot (K2) memiliki berat polong kering tertinggi yaitu 42,36 g. Hal ini diduga pemberian pupuk Grand $\mathrm{K}$ dengan dosis yang tepat dapat memenuhi kebutuhan tanaman, sehingga bagian fisiologis tanaman dapat berjalan secara baik dan dapat membentuk bagian marfologis secara optimal. Marsono dalam Syafruddin dkk, (2012) menyatakan penggunaan dosis pupuk berlebihan dapat mematikan tanaman, sedangkan dosis kurang tidak memberikan efek pertumbuhan seperti yang diharapkan.

\section{Berat Biji Kering Per Tanaman (g)}

Hasil pengamatan berat biji kering kacang tanah setelah dianalisis ragam, menunjukkan interaksi pupuk Petroganik dan Grand $\mathrm{K}$ tidak berpengaruh nyata, tetapi pengaruh utama nyata terhadap berat biji kering. Hasil uji beda nyata jujur (BNJ) peda taraf 5\% dapat dilihat pada Tabel 7.

Tabel 7. Rata-rata Berat Biji Kering Kacang Tanah Per Tanaman dengan Pemberiaan Pupuk Petroganik dan Pupuk Grand K (g)

\begin{tabular}{|c|c|c|c|c|c|}
\hline \multirow{2}{*}{ Petroganik g/plot } & \multicolumn{4}{|c|}{ Grand K g/plot } & \multirow[b]{2}{*}{ Rerata } \\
\hline & K0 (0) & K1 (7) & K2 (14) & K3 (21) & \\
\hline P0 (0) & 16,11 & 17,69 & 26,13 & 22,53 & $20,62 \mathrm{~d}$ \\
\hline P1 (27) & 20,13 & 23,59 & 30,87 & 26,54 & $25,28 \mathrm{c}$ \\
\hline P2 (54) & 26,37 & 27,77 & 32,21 & 30,10 & $29,11 \mathrm{~b}$ \\
\hline P3 (81) & 29,51 & 31,95 & 36,92 & 33,24 & $32,91 \mathrm{a}$ \\
\hline Rerata & $23,03 \mathrm{c}$ & $25,25 \mathrm{bc}$ & $31,53 \mathrm{a}$ & $28,10 \mathrm{~b}$ & \\
\hline
\end{tabular}

Angka-angka pada baris dan kolom yang diikuti huruf kecil yang sama menunjukkan tidak berbeda nyata menurut uji lanjut BNJ pada taraf $5 \%$.

Data pada Tabel 7 menunjukkan pengaruh utama pupuk Petroganik terhadap berat biji kering yang tertinggi pada dosis 81 g/plot (P3) yaitu 32,91 g. Hal ini diduga pemberian dengan dosis yang tepat akan mengoptimalkan penyerapan unsur hara yang mengacu kepada kualitas biji yang dihasilkan. Manfaat lain pupuk Petroganik yaitu menggemburkan tanah, sehingga pembentukan polong dapat berjalan dengan baik dan menghasilkan biji yang berkualitas.

Pada Gambar 2 dibawah memperlihatkan semakin tinggi dosis pupuk yang diberikan, maka semakin tinggi pula berat biji kering yang dihasilkan. Tanpa pupuk Petroganik (P0) menghasilkan berat $20,88 \mathrm{~g}$, sementara itu pada dosis $27 \mathrm{~g} /$ plot (P1) menghasilkan berat 24,98 g, kemudian pada dosis 54 g/plot (P2) menghasilkan berat 29,02 dan pada dosis 81 
$\mathrm{g} /$ plot (P3) menghasilkan berat 33,02 g. Koefisien determinasi $\left(\mathrm{R}^{2}\right)$ yang dihasilkan sebesar 0,997 yang artinya pupuk Petroganik memberikan pengaruh yang sangat kuat terhadap berat biji kering tanaman kacang tanah sebesar $99,7 \%$.

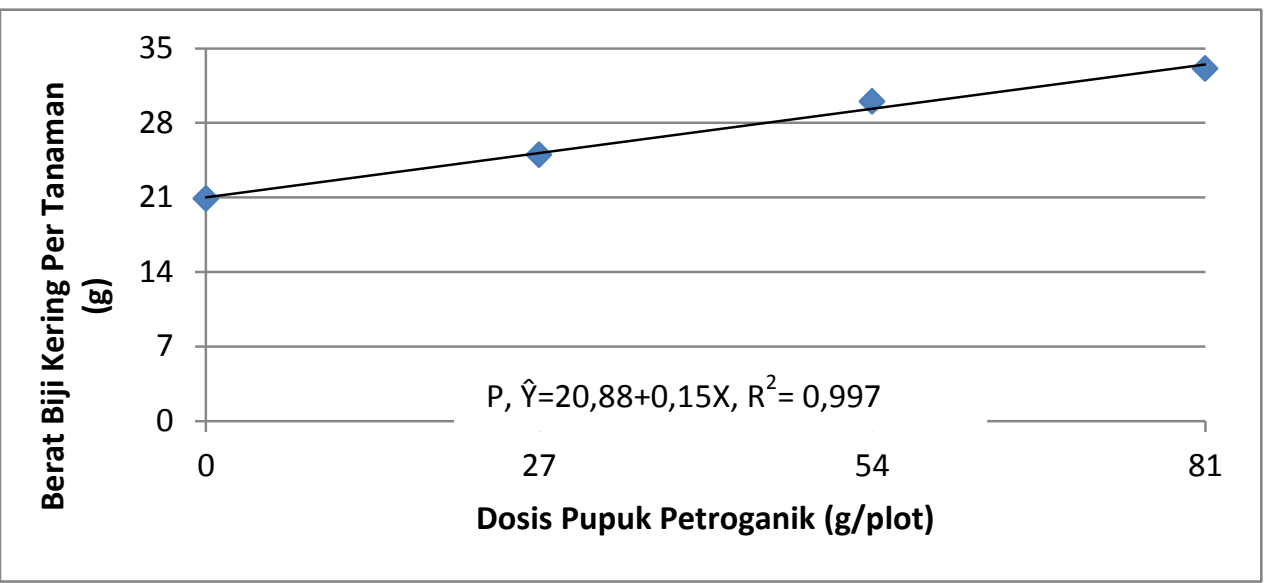

Gambar 2. Grafik Hubungan pemberian pupuk petroganik terhadap berat biji kering per tanaman

Gambar 3 dibawah memperlihatkan berdasarkan persamaan garis duga pupuk Grand $\mathrm{K}$ berpengaruh terhadap berat biji kering pertanaman, dengan memberikan dosis 15,82 g/plot diduga dapat menigkatkan berat biji kering per tanaman 29,56 g. Koefisien determinasi $\left(\mathrm{R}^{2}\right)$ yang dihasilkan 0,77 yang artinya pupuk Grand $\mathrm{K}$ memberikan pengaruh yang sangat kuat terhadap berat biji kering tanaman kacang tanah sebesar $77 \%$.

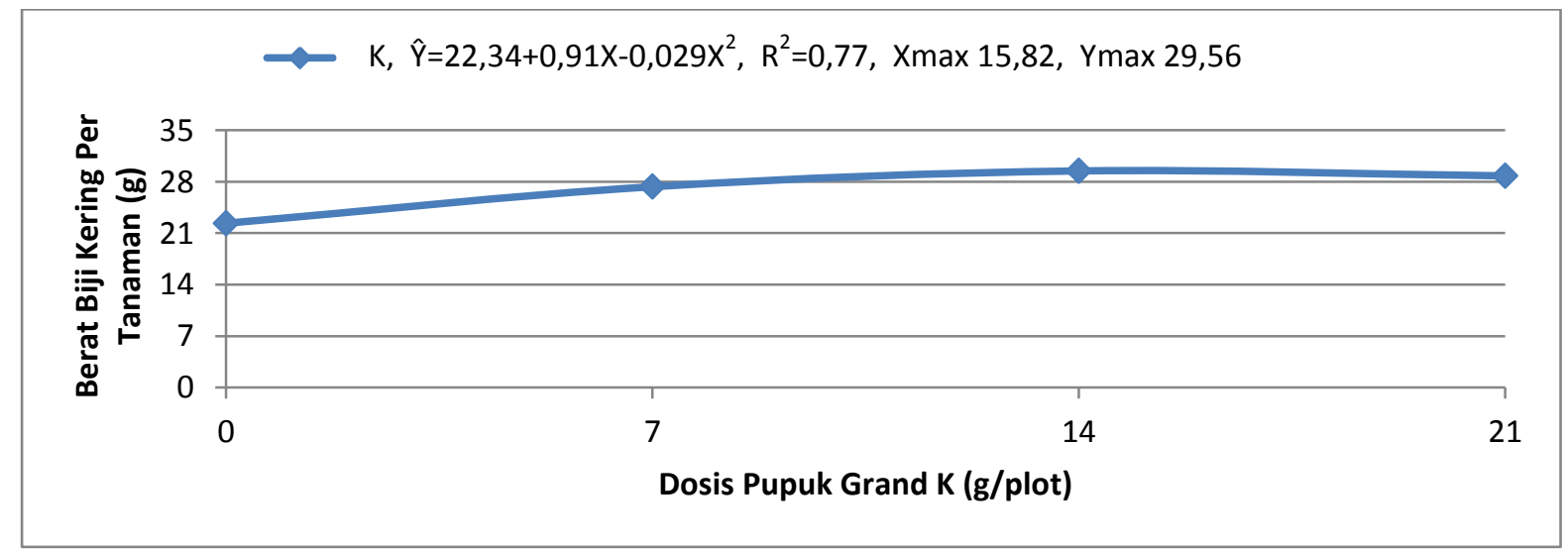

Gambar 3. Grafik Hubungan Pemberian Pupuk Grand K Terhadap Berat Biji Kering Pertanaman Kacang Tanah $(\mathrm{g})$

\section{Persentase Berat Biji Kering Terhadap Polong (\%)}

Hasil pengamatan persentase berat biji kering terhadap polong kacang tanah setelah dianalisis ragam, menunjukkan interaksi pupuk Petroganik dan Grand $\mathrm{K}$ tidak berpengaruh nyata, tetapi pengaruh utama nyata terhadap persentase berat biji kering terhadap polong kacang tanah. Hasil uji beda nyata jujur (BNJ) peda taraf $5 \%$ dapat dilihat pada Tabel 8 .

Data pada Tabel 8 menunjukkan pengaruh utama pupuk Petroganik dengan persentase berat biji kering terhadap polong 42 tertinggi pada dosis P3 (81 g/plot) yaitu 75,45\%. Berdasarkan hasil penelitian banyaknya jumlah polong yang dihasilkan tanaman diduga menyebabkan tidak optimalnya pembentukan biji kacang tanah yang disebabkan nutrisi tersedia banyak di manfaatkan tanaman untuk membentuk polong sehingga mempengaruhi kualitas dari biji yang dihasilkan. Tidak sempurnanya tanaman dalam membentuk biji sangat mempengaruhi persentase berat biji kering terhadap polong.

Pada Tabel 8 juga menunjukkan pengaruh utama pupuk Grand K dengan dosis $14 \mathrm{~g} / \mathrm{plot}$ (K2) memiliki persentase berat biji kering 
terhadap polong tertinggi yaitu $74,07 \%$. Menurut Lakitan (2011), bentuk buah dan biji yang padat berisi merupakan hasil dari penimbunan asimilat dari daun kebuah dan biji. Pemenuhan hara menyebabkan buah dan biji akan memiliki bentuk padat dan berisi sehingga bobot biji dan buah akan tinggi. Ketidakseimbangan asupan asimilat dengan jumlah polong yang dihasilkan akan menurunkan presentase biji terhadap polong pada tanaman kacang tanah.

Tabel 8. Rata-rata Persentase Berat Biji Kering terhadap Polong Kacang Tanah dengan Pemberian Pupuk Petroganik dan Pupuk Grand K (\%)

\begin{tabular}{|c|c|c|c|c|c|}
\hline \multirow{2}{*}{ Petroganik (g/plot) } & \multicolumn{4}{|c|}{ Grand K (g/plot) } & \multirow{2}{*}{ Rerata } \\
\hline & K0 (0) & K1 (7) & $\mathrm{K} 2(14)$ & K3 (21) & \\
\hline P0 (0) & 61,41 & 62,22 & 66,86 & 64,59 & $63,77 \mathrm{~d}$ \\
\hline P1 (27) & 63,05 & 64,96 & 75,08 & 69,48 & $68,14 \mathrm{c}$ \\
\hline P2 (54) & 68,30 & 70,84 & 74,77 & 72,91 & $71,71 \mathrm{~b}$ \\
\hline P3 (81) & 72,53 & 74,05 & 79,57 & 75,64 & $75,45 \mathrm{a}$ \\
\hline Rerata & $66,32 \mathrm{c}$ & $68,02 \mathrm{bc}$ & $74,07 \mathrm{a}$ & $70,66 \mathrm{ab}$ & \\
\hline $\mathrm{KK}=4,51 \%$ & & & BNJ P & & \\
\hline
\end{tabular}

Angka-angka pada baris dan kolom yang diikuti huruf kecil yang sama menunjukkan tidak berbeda nyata menurut uji lanjut BNJ pada taraf $5 \%$.

\section{Bobot 100 Biji (g)}

Hasil pengamatan Bobot 100 biji kacang tanah setelah dianalisis ragam, menunjukkan pengaruh interaksi dan utama pupuk Petroganik dan Grand K nyata terhadap bobot 100 biji. Hasil uji beda nyata jujur (BNJ) peda taraf $5 \%$ dapat dilihat pada Tabel 9. Data pada Tabel 9 menunjukkan dimana dosis pupuk Petroganik $81 \mathrm{~g} /$ plot dan pupuk Grand K $14 \mathrm{~g} / \mathrm{plot}(\mathrm{P} 3 \mathrm{~K} 2)$ memiliki bobot 100 biji tertinggi yaitu dengan berat $49,89 \mathrm{~g}$ dan tidak berbeda dengan perlakuan P3K3, P2K2, P1K2, P3K1 dan P2K3.

Tabel 9. Rata-rata bobot 100 biji kacang tanah dengan pemberiaan pupuk Petroganik dan pupuk Grand K (g)

\begin{tabular}{|c|c|c|c|c|c|}
\hline \multirow{2}{*}{ Petroganik (g/plot) } & \multicolumn{4}{|c|}{ Grand K (g/plot) } & \multirow{2}{*}{ Rerata } \\
\hline & K0 (0) & K1 (7) & K2 (14) & K3 (21) & \\
\hline P0 (0) & $35,95 \mathrm{f}$ & $37,22 \mathrm{ef}$ & $43,86 \mathrm{~cd}$ & $40,19 \mathrm{de}$ & $39,30 \mathrm{~d}$ \\
\hline P1 (27) & 36,88 ef & 39,19 ef & $46,77 \mathrm{abc}$ & $44,61 \mathrm{bc}$ & $41,87 \mathrm{c}$ \\
\hline P2 (54) & $40,56 \mathrm{de}$ & $43,65 \mathrm{~cd}$ & $47,30 \mathrm{abc}$ & $46,18 \mathrm{abc}$ & $44,42 \mathrm{~b}$ \\
\hline P3 (81) & 39,68 ef & $46,70 \mathrm{abc}$ & $49,89 \mathrm{a}$ & $47,90 \mathrm{ab}$ & $46,04 \mathrm{a}$ \\
\hline Rerata & $38,27 \mathrm{~d}$ & $41,69 \mathrm{c}$ & $46,96 \mathrm{a}$ & $44,72 \mathrm{~b}$ & \\
\hline
\end{tabular}

$\mathrm{KK}=3,01 \% \quad \mathrm{BNJ} \mathrm{PK}=3,93 \quad \mathrm{BNJ} \mathrm{P} \& \mathrm{~K}=1,43$

Angka-angka pada baris dan kolom yang diikuti huruf kecil yang sama menunjukkan tidak berbeda nyata menurut uji lanjut BNJ pada taraf $5 \%$.

Agustina dalam Marpaung (2018), menyatakan proses pengisian biji ditentukan oleh tingkat pemenuhan unsur hara dan proses fotosintesis tanaman. Unsur hara yang dibutuhkan tersebut akan saling berkaitan dengan meningkatkan proses fotosintesis tanaman. Nitrogen berfungsi merangsang pembelahan dan diferensasi sel tanaman. Unsur kalium, berfungsi merangsang pembentukan protein, karbohidrat dan aktivitas enzim dalam tubuh tanaman. Dengan berkaitan fungsi unsur hara tersebut menyebabkan pengisian biji tanaman menjadi menjadi maksimal yang artinya berat biji akan tinggi karena bentuk biji akan lebih bernas dan ukuran lebih besar.

\section{KESIMPULAN DAN SARAN}

\section{Kesimpulan}

1. Pengaruh interaksi pupuk Petroganik dan Grand $\mathrm{K}$ berpengaruh nyata terhadap tinggi tanaman, laju pertumbuhan relatif dan berat 100 biji. Kombinasi perlakuan terbaik pada pemberian pupuk Petroganik $81 \mathrm{~g} /$ plot dan pupuk Grand K 14 g/plot (P3K2).

2. Pengaruh utama pupuk Petroganik nyata terhadap semua parameter pengamatan. Perlakuan terbaik adalah dosis $81 \mathrm{~g} / \mathrm{plot}$ (P3). 
3. Pengaruh utama pupuk Grand $\mathrm{K}$ nyata terhadap semua parameter pengamatan. Perlakuan terbaik adalah dosis $14 \mathrm{~g} /$ plot (K2).

\section{Saran}

Berdasarkan hasil penelitian, untuk meningkatkan produksi tanaman kacang tanah disarankan melakukan penelitian lanjutan dengan meningkatkan dosis pupuk Petroganik $81 \mathrm{~g} /$ plot $(900 \mathrm{~kg} / \mathrm{ha})$ dan dikombinasikan dengan pupuk Grand K 14 g/plot (150 kg/ha).

\section{DAFTAR PUSTAKA}

Badan Litbang Pertanian. 2012. Kacang Tanah : Sumber Pangan Sehat dan Menyehatkan. Sinar Tani. Jakarta.

Dinas Tanaman Pangan, Hortikultura dan Perkebunan Provinsi Riau. 2017. Angka Tetap (ATAP) 2017 Produksi Padi dan Palawija Menurut Perhitungan Provinsi Riau. Pekanbaru.

Huda, M. 2018. Penaruh pemberian kompos kulit pisang dan SP-36 terhadap pertumbuhan dan produksi kacang tanah (Arachis hypogaea L.). Skripsi Program Studi Agroteknologi Fakultas Pertanian Universitas Islam Riau. Pekanbaru.

Lakitan. 2011. Fisiologis Pertumbuhan dan Perkembangan Tanaman. Rajawali Pres. Jakarta.

Marbun, S. 2019. Aplikasi bokashi kulit pisang dan pupuk $\mathrm{KCl}$ terhadap pertumbuhan serta produksi bawang merah (Allium cepa L.). Skripsi Program Studi Agroteknologi Fakultas Pertanian Universitas Islam Riau. Pekanbaru.

Marpaung, R. 2018. Pengaruh limbah cair PKS dan pupuk TSP terhadap pertumbuhan dan produksi tanaman kacang hijau ( Vigna radiata L.). Skripsi Program Studi Agroteknologi Fakultas Pertanian Universitas Islam Riau. Pekanbaru.

Murdhiani. 2016. Respon pemberian pupuk kandang ayam dan pupuk kalium terhadap pertumbuhan dan produksi tanaman kacang kedelai (Glycine max (L) Merril). Jurnal Agrosamudra. 3(2) : 4654.

Petrokimia Gresik. 2012. Anjuran Umum Pemupukan Berimbang Menggunakan Pupuk
Majemuk.http://www.petrokimiagresik.co $\mathrm{m} /$ Resources/Docs/dosispupuk\%20majem uk. Diakses tanggal 1 Mei 2018.

Safuan, L dan A. Bahrun. 2012. Pengaruh bahan organik dan pupuk kalium terhadap pertumbuhan dan produksi tanaman melon (Cucumis melo L.) Jurnal Agroteknos. 2(2) : 69-79

Salfila, E. 2014. Hasil kacang tanah (Arachis hypogaea L.) dan jagung manis (Zea mays saccharata Sturt) dengan beberapa pengaturan jarak tanam kacang tanah pada sistem tumpangsari. Skripsi Program Studi Agroteknologi Fakultas Pertanian Universitas Islam Negeri Sultan Syarif Kasim. Pekanbaru. Riau

Syahfitri, H., E. Efendi dan D. Wahyudin. 2019. Respon pertumbuhan dan produksi tanaman kacang tanah (arachis hypogaea L) terhadap pemberian pupuk Grand-K dan ZPT hantu. Jurnal Bernas. 15(1) : 147-164.

Syafruddin, Nurhayati dan R. Wati. 2012. Pengaruh jenis pupuk terhadap pertumbuhan dan hasil beberapa varietas jagung manis. (Zea mays saccharata Sturt). Jurnal Floratek. 7(1) : 107-114.

Yulhasmir. 2009. Respon pertumbuhan dan produksi tanaman kacang tanah (Arachis hypogea. L) terhadap dosis dan waktu pemberian pupuk KCl. Jurnal Agronobis. $1(2): 1-11$. 